\title{
Fusion of Secretory Vesicles Isolated from Rat Liver
}

\author{
Manfred Gratzl and Gerhard Dahl \\ Departments of Physiological Chemistry and Physiology I, \\ University of Saarland, D-6650 Homburg/Saar, \\ Germany
}

Received 23 March 1977; revised 19 December 1977

Summary. Secretory vesicles isolated from rat liver were found to fuse after exposure to $\mathrm{Ca}^{2+}$. Vesicle fusion is characterized by the occurrence of twinned vesicles with a continuous cleavage plane between two vesicles in freeze-fracture electron microscopy. The number of fused vesicles increases with increasing $\mathrm{Ca}^{2+}$-concentrations and is half maximal around $10^{-6} \mathrm{M}$. Other divalent cations $\left(\mathrm{Ba}^{2+}, \mathrm{Sr}^{2+}\right.$, and $\mathrm{Mg}^{2+}$ ) were ineffective. $\mathrm{Mg}^{2+}$ inhibits $\mathrm{Ca}^{2+}$-induced fusion. Therefore, the fusion of secretory vesicles in vitro is $\mathrm{Ca}^{2+}$ specific and exhibits properties similar to the exocytotic process of various secretory cells.

Various substances affecting secretion in vivo (microtubular inhibitors, local anesthetics, ionophores) were tested for their effect on membrane fusion in our system.

The fusion of isolated secretory vesicles from liver was found to differ from that of pure phospholipid membranes in its temperature dependence, in its much lower requirement for $\mathrm{Ca}^{2+}$, and in its $\mathrm{Ca}^{2+}$-specificity. Chemical and enzymatic modifications of the vesicle membrane indicate that glycoproteins may account for these differences.

Membrane fusion is an essential event in a variety of cell functions such as cell fusion, uptake of extracellular material (endocytosis) and release of cell products (exocytosis). Elucidation of the molecular mechanism of membrane fusion has been hampered by the lack of suitable systems for studying this process. Studies with intact cells have not yielded data which lead to ready interpretation concerning subcellular processes. On the other hand, studies with artificial membranes may be only tangentially related to the fusion of biological membranes.

Recently our group investigated the fusion of isolated biological membranes $[16,17,31,33,69,74]$. We observed that $\mathrm{Ca}^{2+}$ specifically induces the fusion of isolated secretory vesicles in a buffered sucrose medium.

Intervesicular fusion of secretory vesicles, as well as the interaction between the cell membrane and the vesicle membrane, was observed in a variety of secretory cells $[2,3,6,18,29,39,53,65]$. Douglas [20] showed that in "compound exocytosis" by mast cells an external stimulus initiates fusion between secretory vesicle membranes and the 
cell membrane. This process is followed by serial fusions of further vesicles to the original vesicle already undergoing exocytosis. Thus, in these cells intervesicular fusion and exocytosis have been shown to be parts of the same process.

Also, intervesicular fusions accompanied exocytosis in glucose-stimulated B-cells of the islet of Langerhans $[6,15]$. Secretory vesicles isolated from pancreatic islets fuse in the presence of $\mathrm{Ca}^{2+}$ at concentrations likely to occur within the cell [16]. In both studies similar changes in the distribution of membrane-associated particles (MAPs) during fusion of secretory vesicles were observed. Thus, we concluded that intervesicular fusion is directly related to exocytosis.

The experiments here described were designed to probe the molecular basis of the secretory process. We first investigated whether fusion of secretory vesicles isolated from hepatocytes occurs under conditions similar to that for vesicles isolated from pancreatic B-cells. Furthermore, drugs known to influence secretion were tested for possible effects on vesicle fusion. Finally, the effect of modifying the membranes of secretory vesicles by enzymes and by chemical reagents was studied.

Preliminary reports of parts of this work have appeared elsewhere $[31,32]$.

\section{Materials and Methods}

\section{Isolation of Secretory Vesicles}

For the isolation of subcellular fractions the livers of female Sprague-Dawley rats $(200-250 \mathrm{~g})$ were used. The animals were starved overnight and given ethanol orally $(0.6 \mathrm{~g} /$ $100 \mathrm{~g}$ body weight) $90 \mathrm{~min}$ before sacrifice. This and the following procedure were carried out as described [28] with the following modifications. To maintain constant $\mathrm{pH}$, all solutions used for the isolation of Golgi-fractions were buffered with $10 \mathrm{~mm}$ cacodylate $(\mathrm{pH} 7.0)$. To assure low $\mathrm{Ca}^{2+}$ concentration, EGTA ${ }^{1}(1 \mathrm{mM})$ was added to all solutions. The excised livers were bleached by perfusing the livers with $10 \mathrm{~mm}$ cacodylate buffer $(\mathrm{pH} 7.0)$ containing $0.25 \mathrm{M}$ sucrose and $1 \mathrm{~mm}$ EGTA (CSE-medium).

Light, intermediate, and heavy fractions were obtained by floating the microsomal fraction in a discontinuous sucrose gradient. Only the light fraction, accumulating at the $0.25-0.6 \mathrm{M}$ sucrose interface, was used in this study. This fraction represents primarily trans-Golgi elements from the secretory Golgi-face [7, 28, 30] and will be called "secretory vesicles" in this report. This fraction was collected, diluted with CSE-medium, and spun down at $60,000 \times g$ for $1 \mathrm{hr}$. The yellowish pellet obtained was resuspended in CSE-medium to obtain a protein concentration around $2 \mathrm{mg} / \mathrm{ml}$ and used for experiments the same day.

1 Abbreviations used: EGTA-ethyleneglycol-2-(2-aminoethyl)-tetraacetic acid; MAPsmembrane associated particles; CSE-medium - 10 mM cacodylate ( $\mathrm{pH} 7.0$ ) containing $0.25 \mathrm{M}$ sucrose and $1 \mathrm{~mm}$ EGTA. 


\section{Incubation Procedures}

$10 \mu \mathrm{l}$ of the vesicle suspension was mixed with $10 \mu \mathrm{l}$ CSE-medium containing reagent(s) under study. After 5 min of incubation in a water bath at $37^{\circ} \mathrm{C}, 10 \mu 1$ of the same solution, containing as a fixative $2 \%$ glutaraldehyde in place of an equal amount of sucrose, was added. Incubation was then continued for $5 \mathrm{~min}$ at $37^{\circ} \mathrm{C}$. Then for cryoprotection, $10 \mu \mathrm{l}$ glycerol was added. After $10 \mathrm{~min}$ at room temperature small droplets $(0.5 \mu \mathrm{l})$ of the suspension were frozen on golden specimen holders in Freon 22 cooled by liquid nitrogen. Modifications of this procedure are indicated where necessary.

\section{Other Methods Used}

The amount of free divalent cations in the solutions (at pH 7.0) was calculated using the stability constants of EGTA complexes with $\mathrm{Ca}^{2+}, \mathrm{Mg}^{2+}, \mathrm{Sr}^{2+}$, or $\mathrm{Ba}^{2+}$ given in the literature [8]. Equal volumes of secretory vesicles in CSE were mixed with CSE containing twice the total amount of divalent cations required to obtain a certain concentration of free cations in the final solution. This procedure at high concentrations of divalent cations leads to a small drop in $\mathrm{pH}$ ( $<0.3$ units), the effect of which on free cation concentrations can be disregarded. $\mathrm{Mg}^{2+}$ does not interfere with $\mathrm{Ca}^{2+}$ since the stability constant for $\mathrm{Mg}^{2+}$ EGTA is smaller by a factor of $10^{7}$ than that of $\mathrm{Ca}^{2+}$ EGTA. Protein was assayed with cristalline bovine serum albumin as a standard [46].

Enzymatic and chemical modification of secretory vesicles was carried out as follows: Before addition of $\mathrm{Ca}^{2+}$, vesicles $(2 \mathrm{mg} / \mathrm{ml})$ were incubated in CSE-medium at $0^{\circ} \mathrm{C}$ for 30 min with bovine trypsin (Boehringer, Mannheim, GFR), pronase (Streptomyces griseus) (Serva, Heidelberg, GFR) or neuraminidase (Clostridium perfringens) (Boehringer, Mannheim, GFR) in concentrations specified under Results. Preincubation with group-specific reagents $\left(10^{-3} \mathrm{M}\right)$ was carried out for $10 \mathrm{~min}$ at $37^{\circ} \mathrm{C}$.

Secretory vesicles were also prepared from rats injected with $0.25 \mathrm{mCi} \mathrm{D-}\left[{ }^{3} \mathrm{H}\right]$ glucosamine or $0.25 \mathrm{mCi} \mathrm{L-}\left[{ }^{3} \mathrm{H}\right]$ leucine (Amersham Buchler, Braunschweig, GFR) in $0.5 \mathrm{ml} 0.9 \%$ $\mathrm{NaCl}$ into the the portal vein of $200 \mathrm{~g}$ rats $60 \mathrm{~min}$ before decapitation. After incubation with trypsin, pronase, or neuraminidase $(50 \mu \mathrm{g} / \mathrm{ml})$ as described above, $\mathrm{MgCl}_{2}$ was added (10 mM final concentration) and vesicles were spun down at $150,000 \times g$ for $30 \mathrm{~min}$ in a Beckman Airfuge. For the analysis of radioactivity aliquots of vesicle suspensions and supernatants were dissolved in $1 \mathrm{ml}$ sodium dodecyl sulfate $(1 \%)$ and $10 \mathrm{ml}$ Scintillator $(0.5 \mathrm{~g}$ p-bis-(o-methylstyryl)-benzene, $5.0 \mathrm{~g} 2.5$-diphenyloxazole and $120 \mathrm{~g}$ naphthalene in sufficient 1.4-dioxane to make 1 liter of solution) was added.

We are indebted to Bayer, Leverkusen, GFR, for diethyl p-nitrophenylphosphate, to Eli Lilly GmbH, Bad Homburg, GFR, for vinblastine as well as A23187, and to Ciba Geigy GmbH, Wehr, GFR, for dibucaine. D600 was obtained from Knoll AG, Ludwigshafen, GFR.

All chemicals not specified were of the purest grade commercially available.

\section{Freeze Fracturing}

Freeze fracturing and replication were processed in a Balzer's device (BAF 300) at $-100^{\circ} \mathrm{C}$. Organic material was removed from the replicas using sodium hypochlorite. After washing in distilled water, replicas were picked up on Formvar-and carbon-coated single hole grids and examined in a Siemens Elmiskop 101 at $100 \mathrm{kV}$. Photographs were taken as positives (platinum deposition: black). Direction of platinum shadowing is indicated by an encircled arrowhead. Fracture faces are denoted according to the nomenclature introduced recently [9]. 


\section{Results}

\section{Cation Specificity}

Rat liver secretory vesicles frozen in suspensions containing $1 \mathrm{~mm}$ EGTA (CSE-medium) were found to be dispersed (Fig. 1). Membraneassociated particles (MAPs) adhered more to the concave $P$-face than to the convex $E$-face and were randomly distributed. Upon increasing the concentration of $\mathrm{Mg}^{2+}, \mathrm{Sr}^{2+}$, or $\mathrm{Ba}^{2+}$ to $10^{-4} \mathrm{M}$ in the incubation medium, vesicles became attached to each other and MAPs were aggregated. ${ }^{2}$ The same changes in the distribution of vesicles in the suspension and in the array of MAPs could be observed if $\mathrm{Ca}^{2+}$ (final concentration $10^{-4} \mathrm{M}$ ) was added to the incubation medium. However, in addition to the morphological changes described above for a series of cations,

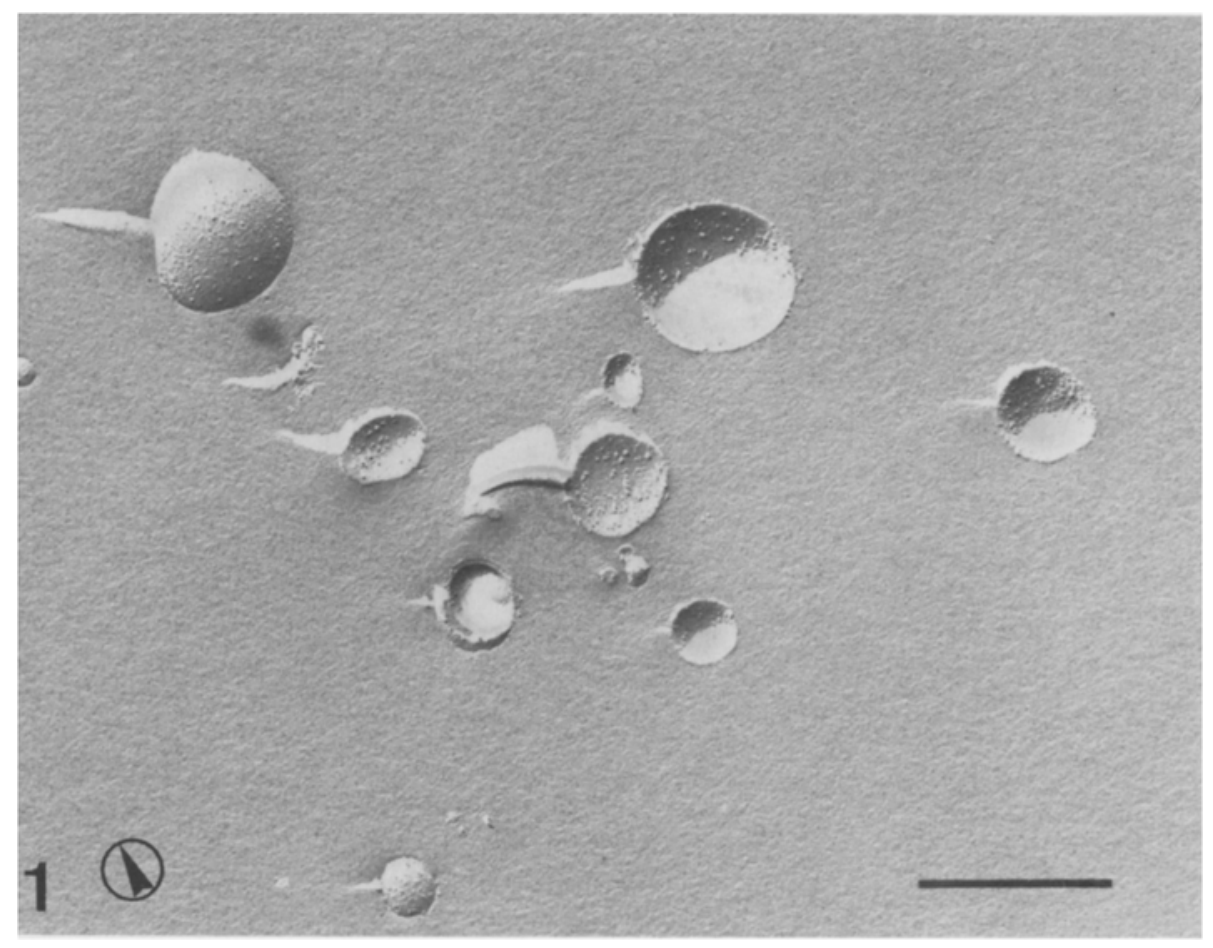

Fig. 1. Secretory vesicles isolated from rat liver incubated in $1 \mathrm{mM}$ EGTA, $0.25 \mathrm{~m}$ sucrose and $10 \mathrm{~mm}$ cacodylate buffer ( $\mathrm{pH}$ 7.0). Secretory vesicles are dispersed. Membrane associated particles (MAPs) stick more to the concave $P$-face than to the $E$-face and are randomly distributed. Encircled arrowhead indicates direction of shadowing. Magnification, $40,000 \times$;

Scale, $0.2 \mu \mathrm{m}$

2 Aggregation of MAPs, because of the small diameters of the vesicles was not determined quantitatively as done earlier [69]. 


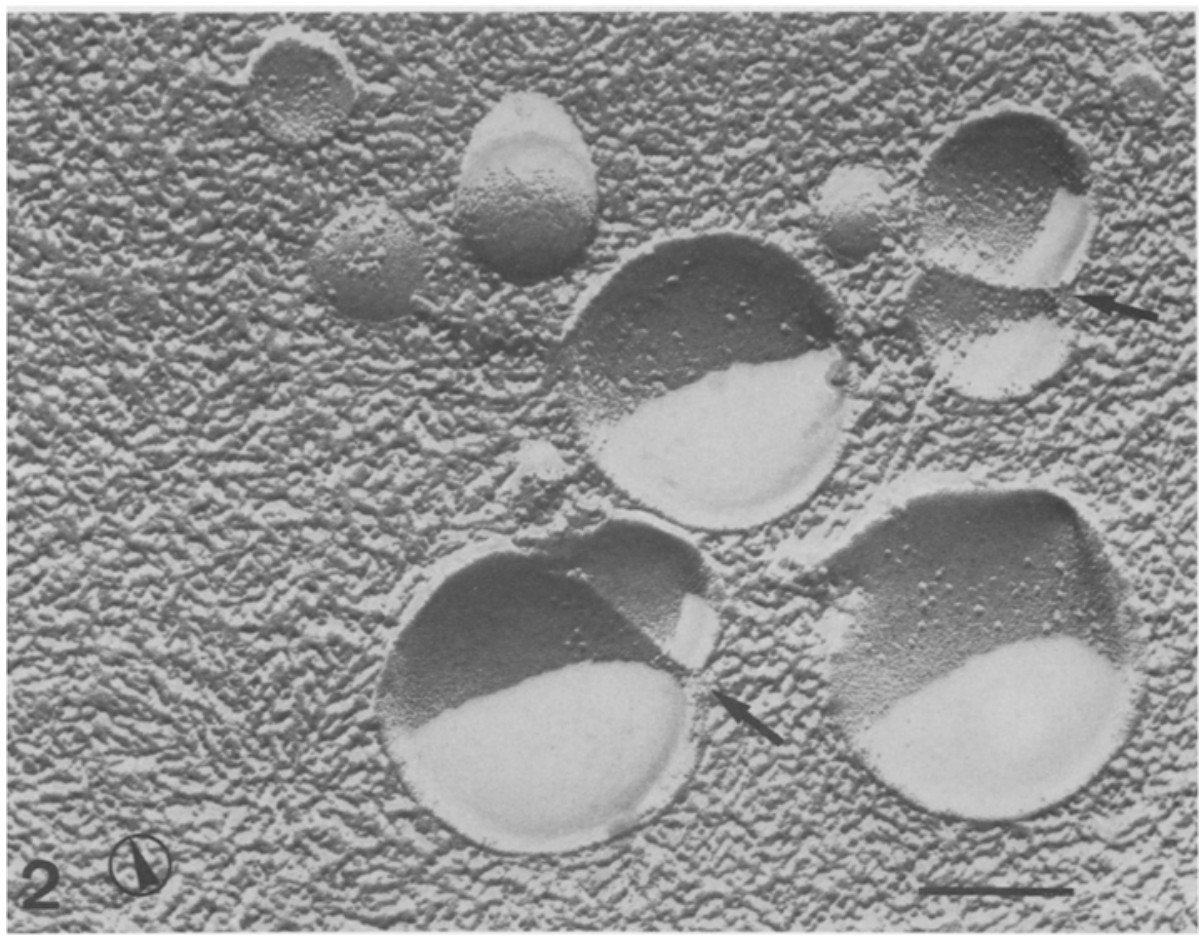

Fig. 2. Secretory vesicles from rat liver in a solution containing $10^{-4} \mathrm{M} \mathrm{Ca}^{2+}$. Vesicles are clustered and fused vesicles can be detected (arrows). Encircled arrowhead indicates direction of shadowing. Magnification, $80,000 \times$; Scale, $0.2 \mu \mathrm{m}$
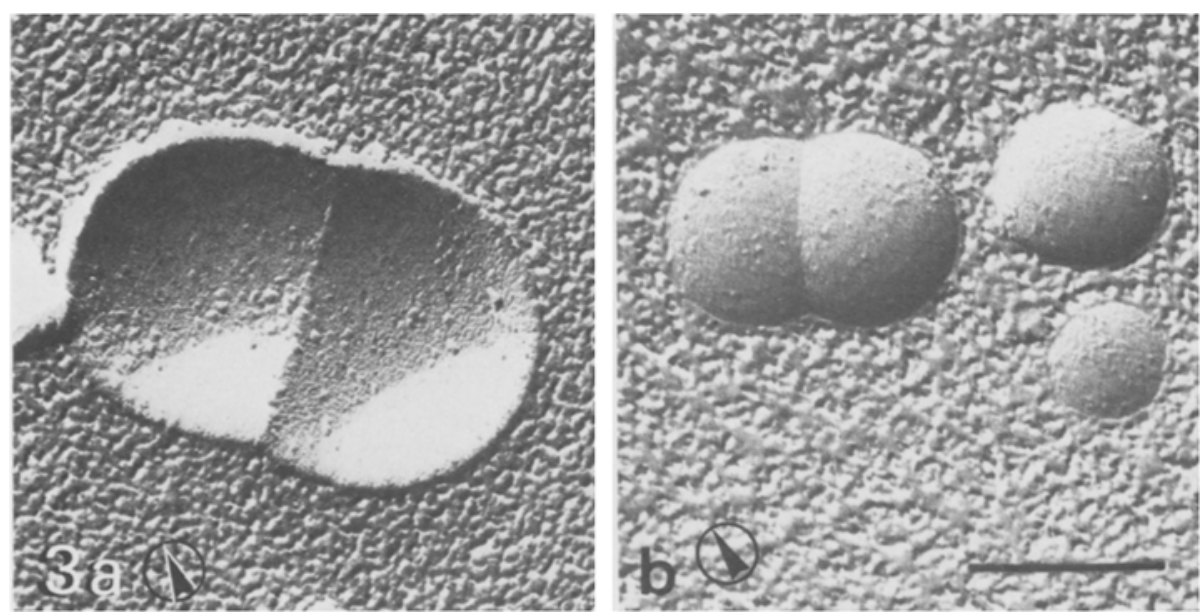

Fig. 3. Secretory vesicles isolated from rat liver in a solution containing $10^{-4} \mathrm{M} \mathrm{Ca}^{2+}$. Twinned vesicles with a continuous cleavage plane in the membrane $P$-face as well as the membrane $E$-face $(a, b)$. Encircled arrowhead indicates direction of shadowing. Magnification, $100,000 \times$; Scale, $0.2 \mu \mathrm{m}$ 
Table 1. Cation dependence of the fusion of rat liver secretory vesicles

\begin{tabular}{ll}
\hline Cations & $\%$ of fused vesicles \\
\hline- & $1.8 \pm 0.5(21)$ \\
$10^{-4} \mathrm{M} \mathrm{Ca}^{2+}$ & $9.9 \pm 1.5(21)$ \\
$10^{-3} \mathrm{M} \mathrm{Ca}^{2+}$ & $8.3 \pm 0.7(5)$ \\
$10^{-4} \mathrm{M} \mathrm{Mg}^{2+}$ & $2.0 \pm 0.4(4)$ \\
$10^{-3} \mathrm{M} \mathrm{Mg}^{2+}$ & $2.4 \pm 0.2(3)$ \\
$10^{-4} \mathrm{M} \mathrm{Sr}^{2+}$ & $2.6 \pm 0.6(4)$ \\
$10^{-3} \mathrm{M} \mathrm{Sr}^{2+}$ & $3.2 \pm 0.6(3)$ \\
$10^{-4} \mathrm{M} \mathrm{Ba}^{2+}$ & $2.0 \pm 0.4(4)$ \\
$10^{-4} \mathrm{M} \mathrm{Ba}^{2+}$ & $2.7 \pm 0.4(3)$ \\
$10^{-4} \mathrm{M} \mathrm{Ca}^{2+}+10^{-4} \mathrm{M} \mathrm{Mg}^{2+}$ & 7.0 \\
$10^{-4} \mathrm{M} \mathrm{Ca}^{2+}+10^{-3} \mathrm{M} \mathrm{Mg}^{2+}$ & 5.0 \\
\hline
\end{tabular}

The experiments were evaluated by counting 400 vesicles for each incubation. The values are the mean $\pm \mathrm{SD}$, where $n$ equals 3 or more. The numbers of experiments $(n)$ is given in parentheses.

a The numbers of fused vesicles here reported are minimum values. The actual numbers must be higher for several reasons: Vesicles were designated as fused if they exhibited a distinct waist. This could only be observed if the long axis of the twinned vesicle did not deviate greatly from the cleavage plane. In addition, the number of intact secretory vesicles capable of fusion is certainly less than the total number of vesicles contained in our preparation. For example, immature and/or damaged vesicles are likely to occur.

fused vesicles could be detected (Fig. 2). These were characterized as twinned vesicles with a continuous cleavage plane in the membrane $P$-face as well as in the membrane $E$-face (Fig. 3).

The vesicles were usually incubated for $5 \mathrm{~min}$. Shorter $(1 \mathrm{~min})$ and longer $(30 \mathrm{~min})$ incubation periods did not change the percentage of fused vesicles induced by $\mathrm{Ca}^{2+}$ in $10^{-4} \mathrm{M}$ or $10^{-6} \mathrm{M}$ concentrations. Incubation with an excess of EGTA after incubation with $\mathrm{Ca}^{2+}$ likewise did not affect the number of twinned vesicles. The data summarized in Table 1 show that among the cations tested only $\mathrm{Ca}^{2+}$ led to fusion of these vesicles. We therefore call the observed fusion a $\mathrm{Ca}^{2+}$-specific fusion of secretory vesicles. The results obtained with $10^{-3} \mathrm{M}$ concentrations of cations did not differ from that with $10^{-4} \mathrm{M}$ concentrations.

\section{Influence of $\mathrm{Ca}^{2+}$ Concentration}

Free $\mathrm{Ca}^{2+}$ concentrations as high as $10^{-4} \mathrm{M}$ do not occur in the cytoplasm of cells. To determine whether isolated secretory vesicles can fuse in media containing free $\mathrm{Ca}^{2+}$ concentration compatible with the intracellular fluid, the percentage of fused vesicles was determined as 


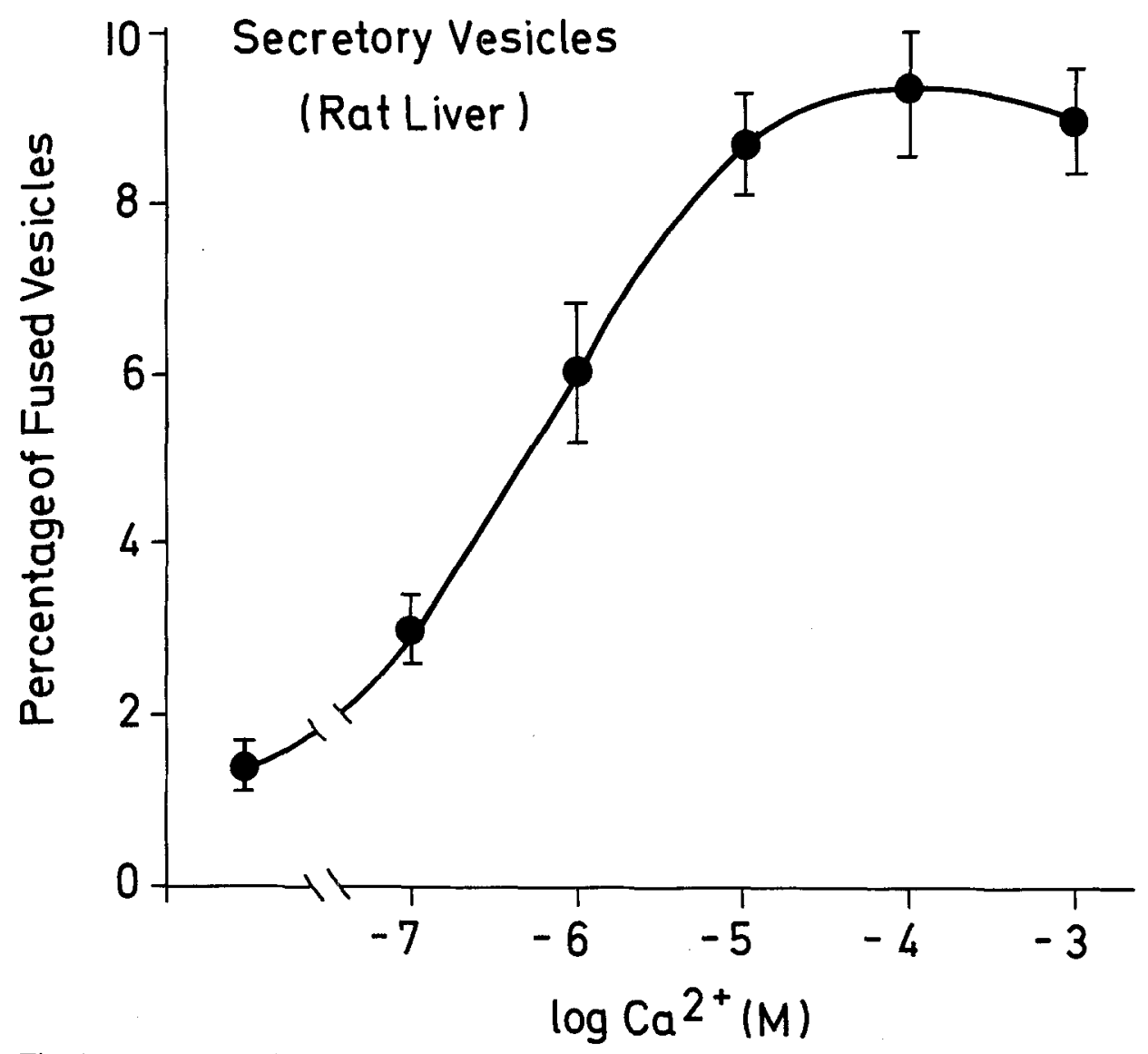

Fig. 4. Percentage of fusion of isolated secretory vesicles as function of $\mathrm{Ca}^{2+}$-concentration. The experiments were evaluated by counting 500 vesicles for each $\mathrm{Ca}^{2+}$-concentration. The values represent the mean of five experiments (SD)

a function of $\mathrm{Ca}^{2+}$ concentrations. As shown in Fig. 4 a sigmoidal curve was obtained and fusion of secretory vesicles was half maximal around $10^{-6} \mathrm{M} \mathrm{Ca}^{2+}$. Therefore, the $\mathrm{Ca}^{2+}$-specific fusion of secretory vesicles described in this investigation in fact increases in the range of normal intracellular concentration of free $\mathrm{Ca}^{2+}$.

\section{Inhibition of $\mathrm{Ca}^{2+}$-Induced Fusion by $\mathrm{Mg}^{2+}$}

Experiments with giant synapses have shown that $\mathrm{Ca}^{2+}$-evoked release of transmitter is inhibited by other divalent cations [50]. To investigate whether this inhibition takes place at the level of membrane fusion, $\mathrm{Mg}^{2+}$ was added to the incubation medium containing $10^{-4} \mathrm{M} \mathrm{Ca}^{2+}$. 
Table 2. Effect of microtubular inhibitors on $\mathrm{Ca}^{2+}$-induced fusion of rat liver secretory vesicles

\begin{tabular}{lc}
\hline Additives in the incubation medium & $\%$ of fused vesicles \\
\hline & \\
& \\
$10^{-4} \mathrm{M} \mathrm{Ca}^{2+}$ & 2.0 \\
$10^{-4} \mathrm{M} \mathrm{Ca}^{2+}+10^{-5} \mathrm{M}$ colchicine & 7.0 \\
$10^{-4} \mathrm{M} \mathrm{Ca}^{2+}+10^{-3} \mathrm{M}$ colchicine & 4.4 \\
$10^{-4} \mathrm{M} \mathrm{Ca}^{2+}+10^{-5} \mathrm{M}$ vinblastine & 9.0 \\
$10^{-4} \mathrm{M} \mathrm{Ca}^{2+}+10^{-3} \mathrm{M}$ vinblastine & 4.5 \\
\hline
\end{tabular}

The experiments were evaluated by counting 500 vesicles for each incubation. Vesicles were preincubated for $5 \mathrm{~min}$ at $37^{\circ} \mathrm{C}$ with colchicine or vinblastine before addition of $10^{-4} \mathrm{M} \mathrm{Ca}^{2+}$. Each value gives the mean of two experiments.

a See footnote $a$, Table 1 .

Equimolar concentrations of $\mathrm{Mg}^{2+}$ decreased the amount of fused vesicles, and an excess of $\mathrm{Mg}^{2+}\left(10^{-3} \mathrm{M}\right)$ further lowered the percentage of fused vesicles (Table 1). The fusion of secretory vesicles in vitro therefore shows the same characteristics as the secretion triggered by injection of $\mathrm{Ca}^{2}+$ into cells.

\section{Effect of Microtubular Inhibitors}

Microtubular inhibitors such as colchicine and vinblastine have been shown to inhibit secretion of protein and lipid from liver into blood plasma $[34,43,63,73]$. Since it is known that these agents in addition to their specific binding to tubulin exhibit unspecific binding to subcellular membranes [72], the effect of colchicine and vinblastine on the $\mathrm{Ca}^{2+}$. induced fusion of isolated secretory vesicles was studied. After preincubation of secretory vesicles with colchicine or vinblastine in $10^{-5} \mathrm{M}$ concentrations, the percentage of fused vesicles was found to decrease (Table 2). Vesicle fusion became even rarer when the concentration of microtubular inhibitor was increased to $10^{-3} \mathrm{M}$.

\section{Effect of Various Agents}

Lysolecithin has been reported to promote $[14,41,60]$ as well as to inhibit membrane fusion $[64,69,70]$. We have found that lysolecithin in very low concentration inhibits the $\mathrm{Ca}^{2+}$-specific fusion of isolated secretory vesicles (Table 3 ). Local anesthetics are known to inhibit virus- 
Table 3. Effect of various agents on $\mathrm{Ca}^{2+}$-induced fusion of rat liver secretory vesicles

\begin{tabular}{lc}
\hline Additives in the incubation medium & $\%$ of fused vesicles ${ }^{\mathrm{a}}$ \\
\hline & 1.7 \\
$10^{-4} \mathrm{M} \mathrm{Ca}^{2+}$ & 10.6 \\
$10^{-4} \mathrm{M} \mathrm{Ca}^{2+}+10^{-6} \mathrm{M}$ lysolecithin & 7.6 \\
$10^{-4} \mathrm{M} \mathrm{Ca}^{2+}+5 \times 10^{-5} \mathrm{M}$ dibucaine & 6.0 \\
$10^{-4} \mathrm{M} \mathrm{Ca}^{2+}+10^{-3} \mathrm{M}$ procaine & 6.2 \\
$10^{-4} \mathrm{M} \mathrm{Ca}^{2+}+10^{-5} \mathrm{M}$ D600 & 10.4 \\
$10^{-4} \mathrm{M} \mathrm{Ca}^{2+}+10^{-4} \mathrm{M} \mathrm{A} 23187$ & 10.6 \\
\hline
\end{tabular}

The experiments were evaluated by counting 500 vesicles for each incubation. All agents were added simultaneously with the $\mathrm{Ca}^{2+}$ ions. Each value gives the mean of two experiments.

a See footnote $a$, Table 1 .

induced cell fusion [61] and secretory processes [22, 67, 71]. Concentrations of dibucaine or procaine, which reduce cell fusion induced by viruses [61], were found to inhibit $\mathrm{Ca}^{2+}$-induced fusion of vesicles (Table 3). In contrast, $\mathrm{Ca}^{2+}$-specific fusion of secretory vesicles was unchanged by incubation with D600 and A23187, agents used as $\mathrm{Ca}^{2+}$. antagonist and $\mathrm{Ca}^{2+}$-ionophore, respectively, in secretion studies.

\section{Temperature Dependence}

Fusion of phospholipid vesicles occurs if the phospholipids are in a "fluid" state. Therefore, a marked increase of membrane fusion can be observed in the range of the specific transition temperature of the lipids investigated $[10,11,58,57]$. Fusion of secretory vesicles exhibits no discontinuity with temperature. As shown in Fig. 5, lowering the temperature led to a monotonous decrease in the percentage of fused vesicles, and fusion could still be detected at $2{ }^{\circ} \mathrm{C}$.

\section{Enzymatic and Chemical Modification of the Vesicle Membrane}

To decide whether proteins are involved in the $\mathrm{Ca}^{2+}$-specific fusion process, the membrane of the secretory vesicles was modified with enzymes and group-specific reagents. Of the sufhydryl blocking reagents tested 4-(hydroxymercuri)benzoic acid was found to be the most powerful in inhibiting fusion of secretory vesicles (Table 4). Agents reacting primarily with aliphatic hydroxyl groups in proteins also decreased the amount 


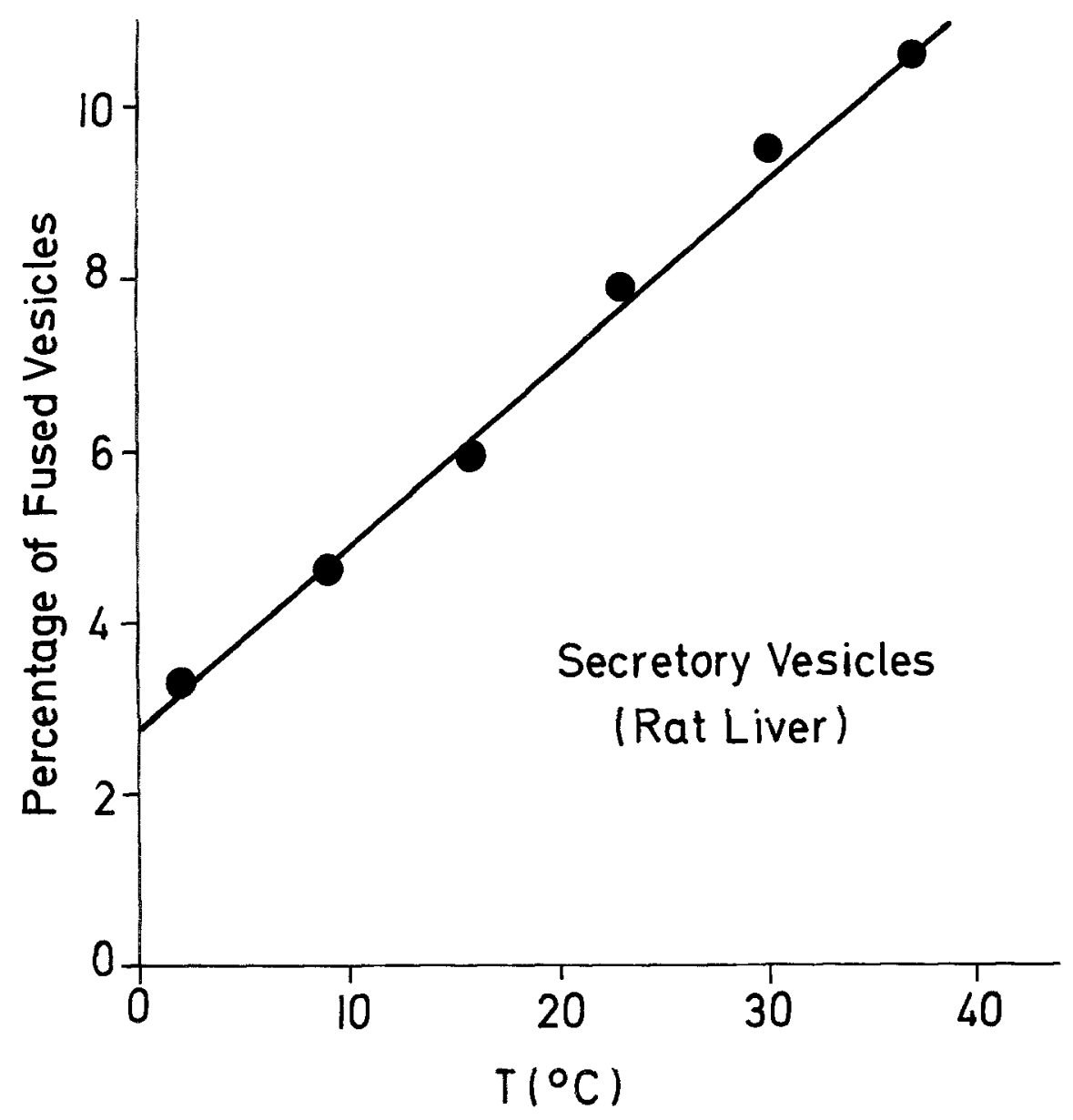

Fig. 5. Temperature dependence of the $\mathrm{Ca}^{2+}$-induced fusion of rat liver secretory vesicles. The values represent the mean of two experiments. The experiments were evaluated by counting 500 vesicles for each temperature. $\mathrm{Ca}^{2+}$-concentration : $10^{-4} \mathrm{M}$

of fused vesicles. It is interesting to note that bis-(4-nitrophenyl)phosphate, carrying a negative charge is a less potent inhibitor of fusion than the structurally related lipophilic compound diethyl-p-nitrophenylphosphate.

The involvement of proteins in $\mathrm{Ca}^{2+}$-specific fusion of secretory vesicles was further corroborated by treatment of the vesicles with proteases. Trypsin as well as pronase reduced vesicle fusion in a concentrationdependent manner (Fig. 6), and both enzymes were effective at very low concentrations. Golgi membranes contain glycoproteins with termi- 
Table 4. Effect of chemical modification of the vesicle membrane on $\mathrm{Ca}^{2+}$-induced fusion of rat liver secretory vesicles

\begin{tabular}{llc}
\hline $\mathrm{Ca}^{2+}$-concentration & $\begin{array}{l}\text { Pretreatment with group-specific reagent } \\
\left(10^{-3} \mathrm{M}\right)\end{array}$ & $\begin{array}{c}\% \text { of fused } \\
\text { vesicles }^{\mathrm{a}}\end{array}$ \\
\hline & & 1.5 \\
$10^{-4} \mathrm{M} \mathrm{Ca}^{2+}$ & - & 10.5 \\
& Sulfhydryl group reagents: & \\
$10^{-4} \mathrm{M} \mathrm{Ca}^{2+}$ & $2,2^{2}$-dinitro-5,5'-dithiodibenzoic acid & 9.0 \\
$10^{-4} \mathrm{M} \mathrm{Ca}^{2+}$ & N-ethylmaleimide & 9.0 \\
$10^{-4} \mathrm{M} \mathrm{Ca}^{2+}$ & 4-(hydroxymercuri)benzoic acid & 2.0 \\
& Aliphatic hydroxyl group reagents: \\
$10^{-4} \mathrm{M} \mathrm{Ca}^{2+}$ & Phenylmethanesulfonyl fluoride \\
$10^{-4} \mathrm{M} \mathrm{Ca}^{2+}$ & Bis-(4-nitrophenyl)phosphate & 8.5 \\
$10^{-4} \mathrm{M} \mathrm{Ca}^{2+}$ & Diethyl-p-nitrophenylphosphate & 10.0 \\
\hline
\end{tabular}

The experiments were evaluated by counting 500 vesicles for each incubation. Vesicles were treated with group-specific reagents $\left(10^{-3} \mathrm{M}\right)$ for $10 \mathrm{~min}$ at $37^{\circ} \mathrm{C}$ before addition of $\mathrm{Ca}^{2+}$. Each value gives the mean of two experiments.

a See footnote $a$, Table 1 .

nal sialic acid residues, the majority of which are localized at the cytoplasmic surface [75]. Treatment of secretory vesicles with neuraminidase, which removes sialic acid from the oligosaccharide moiety of membrane glycoproteins, decreased the $\mathrm{Ca}^{2+}$-specific fusion of these vesicles (Fig. 6). The reduced percentage of fusion is probably not due to binding of neuraminidase to the vesicular membrane. Removal of neuraminidase from the suspension by chromatography on Sepharose $4 B$ did not restore $\mathrm{Ca}^{2+}$-specific fusion.

Secretory vesicles labelled in vivo with $\left[{ }^{3} \mathrm{H}\right] \mathrm{leucine}$ released a considerable amount of radioactivity when incubated with pronase. Trypsin was less effective, and the radioactivity found in the supernatant after incubation with neuraminidase was low (Table 5). Secretory vesicles were also prepared from rats injected with $\left[{ }^{3} \mathrm{H}\right]$ glucosamine, which is efficiently incorporated into protein bound glucosamine and sialic acid [42]. Neuraminidase as well as trypsin or pronase were able to split radioactivity from these vesicles (Table 5).

Enzymatic as well as chemical modification of the vesicle membrane indicates that glycoproteins with sialic acid in terminal position are essential for the $\mathrm{Ca}^{2+}$-specific fusion of secretory vesicles, isolated from rat liver. 


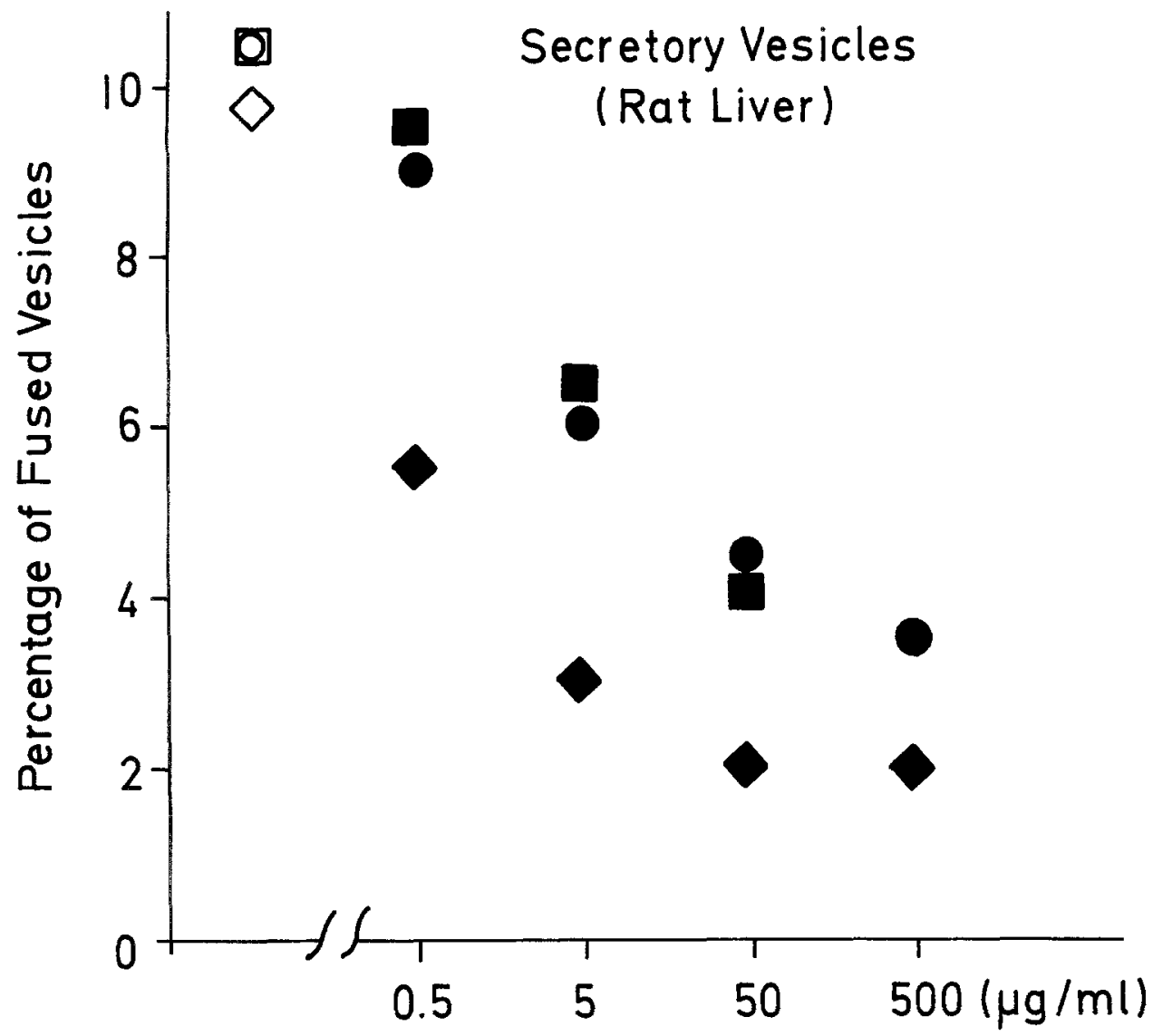

Fig. 6. Effect of pronase, trypsin or neuraminidase on $\mathrm{Ca}^{2+}$-induced fusion of rat liver secretory vesicles. Vesicles were incubated in $\mathrm{Ca}^{2+}$-free medium (CSE) at $0{ }^{\circ} \mathrm{C}$ for $30 \mathrm{~min}$ with trypsin $(\boldsymbol{\bullet})$, pronase $(\bullet)$, neuraminidase $(\bullet)$, or heat-inactivated enzymes $(\square, 0$, $\diamond, 500 \mu \mathrm{g} / \mathrm{ml}$ ). Then $\mathrm{Ca}^{2+}$ was added (final concentration $10^{-4} \mathrm{M}$ ) and the percentage of fused vesicles was determined. The experiments were evaluated by counting 500 vesicles

for each enzyme concentration

Table 5. Effect of pronase, trypsin, or neuraminidase on secretory vesicles labelled with

$\left[{ }^{3} \mathrm{H}\right]$ glucosamine or $\left[{ }^{3} \mathrm{H}\right]$ leucine

\begin{tabular}{llc}
\hline & \multicolumn{2}{l}{$\begin{array}{l}\text { \% of radioactivity released } \\
\text { into the supernatant }\end{array}$} \\
\cline { 2 - 3 } & {$\left[{ }^{3} \mathrm{H}\right]$ glucosamine } & {$\left[{ }^{3} \mathrm{H}\right]$ leucine } \\
\hline Pronase & 2.7 & 20.6 \\
Trypsin & 2.8 & 5.1 \\
Neuraminidase & 4.0 & 1.7 \\
\hline
\end{tabular}

Secretory vesicles isolated from rats injected with $\left[{ }^{3} \mathrm{H}\right]$ glucosamine $(140358 \mathrm{cpm} / \mathrm{mg}$ protein) and those from rats injected with $\left[{ }^{3} \mathrm{H}\right]$ leucine $(28061 \mathrm{cpm} / \mathrm{mg}$ protein) were treated with enzymes as described in Methods, and the percentage of total radioactivity of the secretory vesicles hydrolyzed by pronase, trypsin, or neuraminidase was determined. Each value represents the mean of four experiments. 


\section{Discussion}

In analogy with "electromechanical coupling" in muscle fibers for the chain of events between recognition of a stimulus and release of a secretory product, Douglas and Rubin [27] several years ago introduced the term "stimulus-secretion-coupling." In this process $\mathrm{Ca}^{2+}$ ions were believed to play an important role since $\mathrm{Ca}^{2+}$ ions are required in the extracellular fluid to stimulate a secretory cell successfully $[25,27,35$, $37,52]$. Later from flux measurements in different systems it was concluded that an increase of intracellular $\mathrm{Ca}^{2+}$ may be necessary for the transformation of the stimulus into release of secretory products [13, $23,24,26,36,48,49]$. Recently the rise of intracellular concentrations of $\mathrm{Ca}^{2+}$, detected by injection of aeqorin into nerve terminals, was found to parallel stimulation and transmitter release [45].

Release in the absence of an external stimulus can be evoked with the aid of ionophores which are thought to introduce $\mathrm{Ca}^{2+}$ into cells or, more obviously, by injection of $\mathrm{Ca}^{2+}$ into mast cells [40] and giant synapses [50]. $\mathrm{Mg}^{2+}$ was ineffective in causing exocytosis in mast cells [40]. Likewise $\mathrm{Mg}^{2+}$ or $\mathrm{Mn}^{2+}$ did not lead to transmitter release from the giant synapse but were found to antagonize the $\mathrm{Ca}^{2+}$ effect [50].

Although the requirement of $\mathrm{Ca}^{2+}$ for secretion is well established, the exact role played by $\mathrm{Ca}^{2+}$ is as yet unknown.

It is generally accepted that most of the secretory cells release their product via exocytosis. Exocytosis requires the fusion of the vesicle membrane with the plasma membrane. However, as already shown in several cells, the stimulus for secretion not only induces the fusion of the plasma membrane with the vesicular membrane but also of secretory vesicles among themselves $[2,3,6,18,29,39,53,65]$. Thus the exocytotic process appears to involve both types of fusions. This type of secretion is called "compound exocytosis" and is shown in a cinematographic study by Douglas [20] in mast cells.

Recently, "compound exocytosis" was observed in glucose-stimulated pancreatic B-cells. In these cells both intervesicular fusions and fusions of the secretory vesicles with the plasma membrane are characterized by a striking redistribution of MAPs $[6,15]$. Intervesicular fusion similar to that observed in vivo was observed in vitro for the first time in the authors' laboratories by incubation of isolated secretory vesicles from the islet of Langerhans with low concentrations of $\mathrm{Ca}^{2+}\left(10^{-6} \mathrm{M}\right)$ [16]. 


\section{$\mathrm{Ca}^{2+}$-Specificity, Antagonism with $\mathrm{Mg}^{2+}$ and Temperature Dependence}

In the present study secretory vesicles isolated from rat liver were found to fuse in vitro, and the membrane structure changes during this process with respect to the distribution of MAPs are similar to those observed with secretory vesicles of pancreatic B-cells. Fusion of secretory vesicles isolated from hepatocytes as well as those of pancreatic islet cell [16] and the neurohypophysis [33,74] was $\mathrm{Ca}^{2+}$-specific; other cations were ineffective in triggering the fusion. Furthermore, the fusion of secretory vesicles was half maximal at $10^{-6} \mathrm{M} \mathrm{Ca}^{2+} \cdot \mathrm{Mg}^{2+}$, which was unable to evoke fusion, was found to inhibit $\mathrm{Ca}^{2+}$-induced fusion of isolated secretory vesicles isolated from rat liver in a concentrationdependent manner. We have shown that secretory vesicles isolated from bovine adrenal medulla fuse under similar conditions [17]. Thus, fusion of secretory vesicles in vitro not only occurs in the range of free $\mathrm{Ca}^{2+}$ expected intracellularly $[19,45,66]$. It also parallels the properties of secretion triggered by injection of ions $[40,50]$ : Both are $\mathrm{Ca}^{2+}$-specific and the $\mathrm{Ca}^{2+}$-specific effect is antagonized by $\mathrm{Mg}^{2+}$. The only experiment which disagrees with this parallel behavior is reported by Miledi, who induced transmitter release by injecting $\mathrm{Sr}^{2+}$ into nerve terminals [50]. In these experiments, as well in others, where the ionic composition of a cell was changed by injection of ions, use of ionophores, or replacement of ions in the extracellular fluid, the results are difficult to interpret, since an intracellular redistribution of $\mathrm{Ca}^{2+}$ by other cations cannot be ruled out. In this context it is of interest to note that release of intravesicular vasopressin in a suspension containing sheets of cell membrane [33] resembles closely the ionic requirements for intervesicular fusion of secretory vesicles from rat liver and other tissues $[16,17,33$, 74].

Current knowledge about the fusion of membranes is mainly based on experiments with phospholipid membranes. Fusion of phospholipid vesicles was induced by $\mathrm{Ca}^{2+}$ at concentrations of $0.1 \mathrm{~mm}$ or greater, depending on the type of phospholipids studied $[11,47,51,55,57$, 58]. The requirement for such high concentration of $\mathrm{Ca}^{2+}$ contrasts with the low concentrations of $\mathrm{Ca}^{2+}\left(10^{-7} \mathrm{M}\right)$ sufficient to induce fusion of secretory vesicles. In addition phospholipid fusion can also be induced by other cations $[11,47,51,58]$, certain phospholipids being more susceptible to fusion by $\mathrm{Ca}^{2+}$ than by $\mathrm{Mg}^{2+}[51,57,58]$. In contrast, fusion of secretory vesicles isolated from rat liver is specifically governed by $\mathrm{Ca}^{2+}$. 
Membrane fluidity seems to be an important prerequisite for the fusion of pure phospholipid membranes since the rate of fusion increases dramatically at or above the phase transition of the phospholipids [10, $11,57,58]$. The fusion of secretory vesicles isolated from rat liver displayed no abrupt changes between 2 and $37^{\circ} \mathrm{C}$. The detection of membrane fusion of biological membranes in vitro at low temperatures is not surprising: Exposed to cold, neurohypophyses [21], synaptosomes [62], and neurosecretosomes [4] release secretory products in the absence or presence of an external stimulus.

The simultaneous release of vasopressin, ATP, and protein by the isolated neurohypophysis, which still retained lactic dehydrogenase and potassium ions, has led to the conclusion that the cold-induced release is an exocytotic event [38]. Recently exocytotic profiles were detected when isolated neurohypophyses or neurosecretosomes were exposed to cold [33]. Pancreatic B-cells also released insulin when exposed to cold [44]. Under this condition an increase of exocytotic profiles in freezefractured pancreatic islets, as compared to unstimulated islets at $37^{\circ} \mathrm{C}$, was observed ${ }^{3}$, thus suggesting that an exocytotic mechanism could well contribute to cold-induced release.

\section{Effect of Various Substances on $\mathrm{Ca}^{2+}$-induced Fusion}

Since membrane fusion seems to be an essential process of secretion by exocytosis, it appeared worthwhile to study this process in vitro and to verify if substances affecting secretion interfere with fusion in vitro.

To substantiate involvement of microtubules in the secretory process, drugs such as colchicine and vinblastine are often used. Secretion of lipids and proteins from the hepatocyte into blood plasma was found to be inhibited by these substances $[34,43,63,73]$. On the other hand, colchicine is known to bind unspecifically to membranes isolated from rat and mouse liver [72], and therefore an effect on the membrane level has to be taken into account. Although it was reported that colchicine does not affect certain intracellular fusion processes [59], it seemed important to study the effect of microtubular inhibitors on membrane fusion with Golgi membranes since colchicine in the hepatocyte was shown to inhibit the discharge of secretory vesicles [5]. The secretory vesicles used in this study are isolated in the cold. Under these conditions microtubules are depolymerized and therefore virtually absent in the suspension

3 Dahl, G., and Henquin, J.C. (in preparation). 
of purified secretory vesicles. Despite this fact, $\mathrm{Ca}^{2+}$-induced fusion was found to be reduced by colchicine and vinblastine in $10^{-5} \mathrm{M}$ concentrations. Increasing the concentration of these drugs to $10^{-3} \mathrm{M}$ inhibited to a remarkable degree the $\mathrm{Ca}^{2+}$-triggered fusion. Therefore, effects of microtubular inhibitors on intact cells must be interpreted with caution. Disruption of microtubules as well as an effect at the membrane level may contribute to the inhibition of secretion.

The mechanism by which local anesthetics inhibit membrane fusion in our system remains to be clarified. It is interesting to note in this context that local anesthetics are able to displace $\mathrm{Ca}^{2+}$ from membranes (cf. [71]), to lower the transition temperature of phospholipids [54] and to inhibit $\mathrm{Ca}^{2+}$-induced fusion of phospholipid vesicles [58].

D600, a compound suggested to be a $\mathrm{Ca}^{2+}$-antagonist in several types of intact cells, did not influence the $\mathrm{Ca}^{2+}$-specific fusion of hepatic secretory vesicles. Also, the divalent ionophore A23187 exhibits no effect on the $\mathrm{Ca}^{2+}$-induced fusion of isolated secretory vesicles. Therefore, it can be concluded that $\mathrm{Ca}^{2+}$ does not penetrate the vesicle membrane before inducing fusion.

We have found that the fusion of secretory vesicles isolated from rat liver is inhibited by lysolecithin. This finding is in accord with similar inhibitions reported for fusion of intact myoblasts $[64,70]$ as well as for isolated myoblast cell membranes [69]. In contrast, chemically induced fusion of cells was shown to be enhanced by lysolecithin $[14,43,60]{ }^{4}$ Studies with phospholipid membranes have not clarified the effect of lysolecithin on fusion $[10,56]$. The results obtained so far indicate that membrane fusion occurring naturally during muscle development or secretion is inhibited by lysolecithin.

\section{Effect of Group-Specific Reagents and Enzymes}

The requirement for low concentrations of $\mathrm{Ca}^{2+}\left(10^{-7} \mathrm{M}\right)$ and the observed $\mathrm{Ca}^{2+}$-specificity for fusion of isolated secretory vesicles claim for membrane factor(s) favoring fusion which are absent in phospholipid membranes. Modification of secretory vesicle membranes by proteases and group-specific reagents as well as removal of sialic acid from the outer surface of the vesicular membrane reduces the ability of secretory vesicles to fuse. Thus, glycoproteins may play a strategic role in the fusion process of the biological membranes studied.

4 Chemically induced fusion of cells likewise is facilitated by preincubation with neuraminidase [1], while fusion of secretory vesicles is inhibited by removal of sialic acid. 
Fusion of isolated microsomal membranes, in contrast to Golgi-derived membranes, has not been observed [31]. Therefore, in the Golgi apparatus a reaction making vesicles "fusion competent" must occur. According to our findings, removal of sialic acid residues from the cytoplasmic side of isolated Golgi-derived secretory vesicles stops $\mathrm{Ca}^{2+}$-specific fusion. Since sialyltransferase is localized in the Golgi-apparatus [68], this enzyme might catalyze the terminal step in rendering the secretory vesicles competent for fusion and is of paramount importance for the secretion of intravesicular compounds into the blood stream.

The authors thank Drs. W. Berger, R. Stämpli, and V. Ullrich for continuous interest in this study. We are indebted to Mrs. P. Traylor for expert help during the preparation of this manuscript. We thank Mrs. M. Elis, Mrs. I. Kümmel, and Mr. R. Weiss for excellent technical assistance.

This work was supported by the Deutsche Forschungsgemeinschaft, Sonderforschungsbereich 38 "Membranforschung", Bad Godesberg.

\section{Appendix}

The cleavage of two vesicles in contact exhibits three different images. As outlined in Fig. 7, the membrane faces in this case are separated by a step $(>80 \AA)$ in the cleavage plane produced by the transition from one to the other vesicular membrane. Such a step must not be present if the membranes of two vesicles are partially fused (Fig. 7).

\section{Freeze-cleaving of Vesicles}

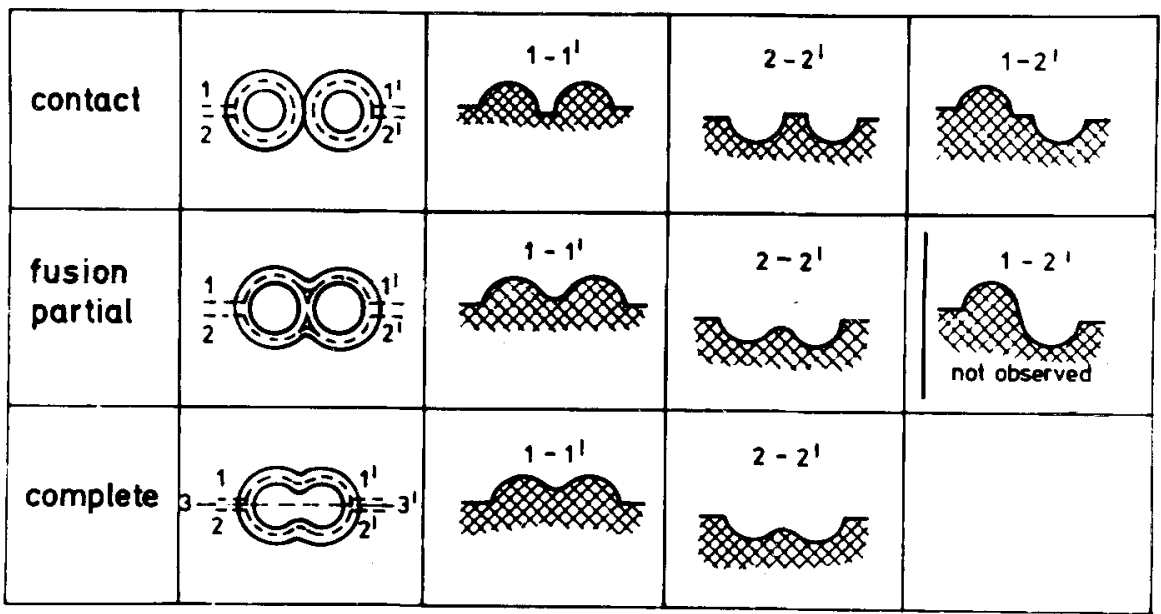

Fig. 7. Scheme of cleavage of vesicles in contact, partially or completely fused. A fracture following line $1-1^{\prime}$ exposes membrane $E$-faces, $2-2^{\prime}$ membrane $P$-faces. Cleavage through the vesicle content is indicated by line $3-3^{\prime}$ 

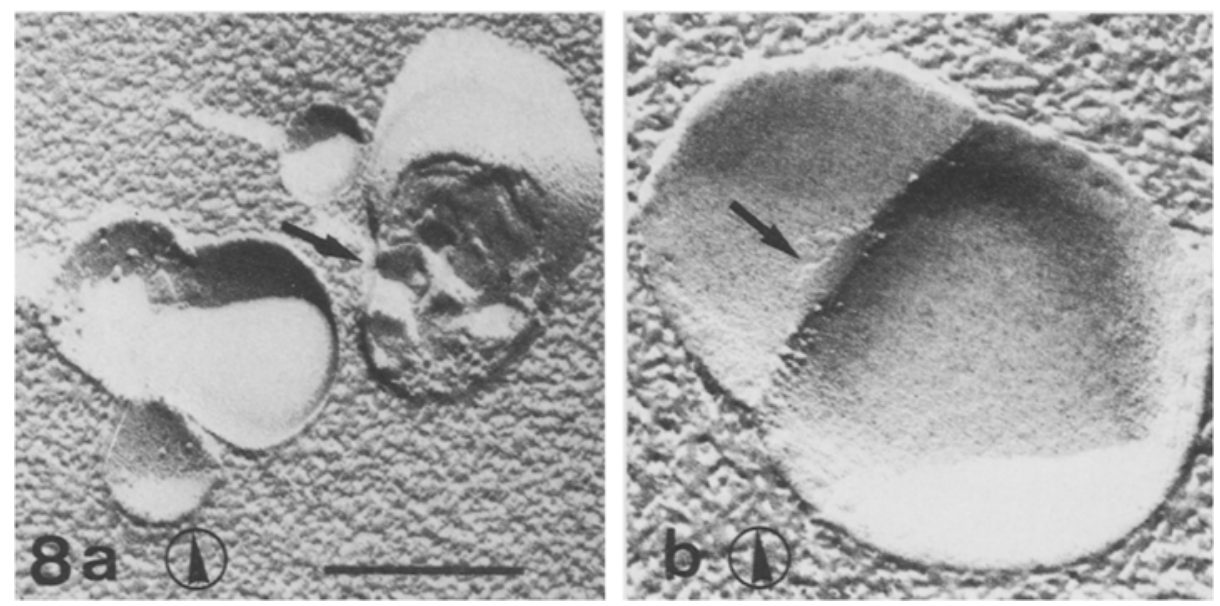

Fig. 8

However, in suspensions containing $\mathrm{Ca}^{2+}$ we never observed "twinned vesicles" with a continuous cleavage plane following the concave $P$-face of one vesicle to the convex $E$-face of the neighboring one. This indicates that the twinned vesicles were completely fused (Fig. 7). Complete fusion is further demonstrated by deep etching (Fig. 8 b). A small patch membrane in the waist of fused vesicles represents the inner surface of the vesicle membrane which rules out the presence of a septum in this area. Continuity of the content of fused vesicles can also be followed in "twinned vesicles" where the cleavage plane deviated from the membranes into the VLDL-filled interior (Fig. 8a). The twinned structure of completely fused vesicles does not differ from that found in stimulated secretory cells $[2,3,6,12,18,29,39,53,65]$.

Magnification of Fig. 8, 100,000×; scale, $0.2 \mu \mathrm{m}$.

\section{References}

1. Ahkong, Q.F., Tampion, W., Lucy, J.A. 1975. Promotion of cell fusion by divalent cation ionophore. Nature (London) 256:208

2. Amsterdam, A., Ohad, J., Schramm, M. 1969. Dynamic changes in the ultrastructure of the acinar cell of rat parotid gland during the secretory cycle. J. Cell Biol. 41:753

3. Andrew, R.D., Shivers, R.R. 1976. Ultrastructure of neurosecretory granule exocytosis by crayfish sinus gland induced with ionic manipulations. J. Morphol. 550:253 
4. Baker, R.C., Vilhardt, N., Hope, D.B. 1975. Cold-induced release of hormones and proteins from nerve endings isolated from bovine neural lobes. J. Neurochem. 24:1091

5. Banerjee, D., Manning, C.P., Redman, C.M. 1976. The in vivo effect of colchicine on the addition of galactose and siolic acid to rat hepatic serum glycoproteins. $J$. Biol. Chem. 251:3887

6. Berger, W., Dahl, G., Meissner, H.P. 1975. Structural and functional alterations in fused membranes of secretory granules during exocytosis in pancreatic islet cells of the mouse. Cytobiologie 12:119

7. Bergeron, J.J.M., Ehrenreich, J.H., Siekewitz, P., Palade, G.E. 1973. Isolation of Golgi fractions from rat liver. II. Biochemical characterization. J. Cell Biol. 59:73

8. Boyd, S., Bryson, A., Nancollas, G.H., Torrance, K. 1965. Thermodynamics of ion association: XII. EGTA complexes with divalent metal ions. J. Chem. Soc. 7353

9. Branton, D., Bullivant, S., Gilula, N., Karnovsky, M., Moor, H., Mühlethaler, K., Northcote, N., Packer, L., Satir, B., Satir, P., Speth, V., Staehlin, L., Weinstein, R. 1975. Freeze-etching nomenclature. Science 190:54

10. Breisblatt, W., Ohki, S. 1975. Fusion in phospholipid spherical membranes. I. Effect of temperature and lysolecithin. J. Membrane Biol. 23:385

11. Breisblatt, W., Ohki, S. 1976. Fusion in phospholipid spherical membranes. II. Effect of cholesterol, divalent ions and pH. J. Membrane Biol. 29:127

12. Burwen, S.J., Satir, B.H. 1977. A freeze fracture study of early membrane events during mast cell secretion. $J$. Cell Biol. 73:660

13. Case, R.M., Clausen, T. 1973. The relationship between calcium exchange and enzyme secretion in the isolated rat pancreas. J. Physiol. (London) 235:75

14. Croge, C.M., Sawicki, W., Kritchewsky, D., Koproowski, H. 1971. Induction of homokaryocyte, heterokaryocyte and hybrid formation by lysolecithin. Exp. Cell Res. 67:427

15. Dahl, G., Berger, W., Meissner, H.P. 1976. Intracellular membrane junctions during the exocytosis of insulin. J. Physiol. (Paris) 72:703

16. Dahl, G., Gratzl, M. 1976. Calcium-induced fusion of isolated secretory vesicles from the islet of Langerhans. Cytobiologie 12:344

17. Dahl, G., Gratzl, M., Ekerdt, R. 1976. In vitro fusion of secretory vesicles isolated from pancreatic B-cells and from the adrenal medulla. J. Cell Biol. 70:180a

18. De Virgilis, G., Meldolesi, J., Clementi, F. 1968. Ultrastructure of growth hormone producing cells of rat pituitary after injection of hypothalamic extract. Endocrinology 83:1278

19. Dipolo, R., Requena, J., Brinley, F.J., Mullins, L.J., Scarpa, A., Tiffert, T. 1976. Ionized calcium concentrations in squid axons. J. Gen. Physiol. 67:433

20. Douglas, W.W. 1974. Involvement of calcium in exocytosis and the exocytosis-vesiculation sequence. Biochem. Soc. Symp. 39:1

21. Douglas, W.W., Ishida, A. 1965. The stimulant effect of cold on vasopressin release from the neurohypophysis in vitro. J. Physiol. (London) 179:185

22. Douglas, W.W., Kanno, T. 1967. The effect of amethocaine on acetylcholine-induced depolarization and catecholamine secretion in the adrenal chromaffin cell. Br.J. Pharmac. Chemother. 30:612

23. Douglas, W.W., Poisner, A.M. 1962. On the mode of acetylcholine in evoking adrenal medullary secretion: Increased uptake of calcium during the secretory response. $J$. Physiol. (London) 162:385

24. Douglas, W.W., Poisner, A.M. 1963. The influence of calcium on the secretory response of the submaxillary gland to acetylcholine or to noradrenaline. J. Physiol. (London) $165: 528$

25. Douglas, W.W., Poisner, A.M. 1964. Stimulus-secretion coupling in a neurosecretory organ: The role of calcium in the release of vasopression from the neurohypophysis. J. Physiol. (London) 172:1 
26. Douglas, W.W., Poisner, A.M. 1964. Calcium movement in the neurohypophysis of the rat and its relation to the release of vasopression. J. Physiol. (London) 172:19

27. Douglas, W.W., Rubin, R.P. 1961. The role of calcium in the secretory response of the adrenal medulla to acetylcholine. J. Physiol. (London) 159:40

28. Ehrenreich, J.H., Bergeron, J.J.M., Siekevitz, P., Palade, G.E. 1973. Golgi fractions prepared from rat liver homogenates. I. Isolation procedure and morphological characterization. J. Cell Biol. 59:45

29. Ekholm, R., Zelander, T., Edlund, Y. 1962. The ultrastructural organization of the rat pancreas. 1. Acinar cell. J. Ultrastruc. Res. 7:61

30. Farquar, M.G., Bergeron, J.J.M., Palade, G.E. 1974. Cytochemistry of Golgi fractions prepared from rat liver. J. Cell Biol. 60:8

31. Gratzl, M., Dahl, G. 1976. $\mathrm{Ca}^{2+}$-induced fusion of Golgi-derived secretory vesicles isolated from rat liver. FEBS Lett. 62:142

32. Gratzl, M., Dahl, G. 1976. Fusion of Golgi-derived secretory vesicles isolated from rat liver. J. Cell Biol. 70:241a

33. Gratzl, M., Dahl, G., Russell, J.T., Thorn, N.A. 1977. Fusion of neurohypophyseal membranes in vitro. Biochim. Biophys. Acta 470:45

34. Gratzl, M., Schwab, D. 1976. The effect of microtubular inhibitors on secretion from liver into blood plasma and bile. Cytobiologie 13:199

35. Grodsky, G.M., Bennett, L.L. 1966. Cation requirement for insulin release in the isolated perfused pancreas. Diabetes 15:910

36. Hellman, B., Sehlin, J., Täljedahl, I.B. 1971. Caclium uptake by pancreatic $\beta$-cells as measured with the aid of ${ }^{45} \mathrm{Ca}$ and mannitol- ${ }^{3} \mathrm{H}$. Am. J. Physiol. 221:1795

37. Hokin, L.E. 1966. Effects of calcium omission on acetylcholine stimulated amylase secretion and phospholipid synthesis in pigeon pancreas slices. Biochim. Biophys. Acta $115: 219$

38. Hong, J.S., Poisner, A.M. 1974. Effect of low temperature on the release of vasopressin from the isolated bovine neurohypophysis. Endocrinology 94:324

39. Ichikawa, A. 1965. Fine structural changes in response to hormonal stimulation of the perfused canine pancreas. J. Cell Biol. 24:369

40. Kanno, T., Cochrane, D.E., Douglas, W.W. 1973. Exocytosis (secretory granule extrusion) induced by injection of calcium into mast cells. Can. J. Physiol. Pharmacol. 51:1001

41. Keay, L., Weiss, S.A., Circulis, N., Wildi, B.S. 1972. Lysolecithin-induced fusion of fibroblasts. In Vitro 8:19

42. Lawford, G.R., Schachter, H. 1966. Biosynthesis of glycoprotein by liver. J. Biol. Chem. 241:5408

43. Le Marchand, Y., Patzelt, C., Assimacopoulos-Jeannet, F., Loten, E.G., Jeanrenaud, B. 1974. Evidence for a role of the microtubular system in the secretion of newly synthesized albumin and other proteins by the liver. J.' Clin. Invest. 53:1515

44. Lernmark, A. 1971. Isolated mouse islet as a model for studying insulin release. Acta Diabetol. Lat. 8:649

45. Llinás, R., Nicholson, C. 1975. Calcium role in depolarization-secretion coupling: An aequorin study in squid giant synapse. Proc. Nat. Acad. Sci. USA 72:187

46. Lowry, O.H., Rosebrough, N.J., Farr, A.L., Randall, R.J. 1951. Protein measurement with the Folin phenol reagent. J. Biol. Chem. 193:265

47. Maeda, T., Ohnishi, S. 1974. Membrane Fusion. Transfer of phospholipid molecules between phospholipid bilayer membranes. Biochem. Biophys. Res. Commun. 60:1509

48. Malaisse-Lagae, F., Malaisse, W.J. 1971. Stimulus-secretion coupling of glucose-induced insulin release. III. Uptake of ${ }^{45} \mathrm{Ca}$ by isolated islets of Langerhans. Endocrinology 88: 72 
49. Matthews, E.K., Peterson, O.H., Williams, J.A. 1973. Pancreatic acinar cells: Acetylcholine-induced membrane depolarization, calcium efflux and amylase release. J. Physiol. (London) 234:689

50. Miledi, R. 1973. Transmitter release induced by injection of calcium ions into nerve terminals. Proc. R. Soc. London B 183:421

51. Miller, C., Racker, E. 1976. Fusion of phospholipid vesicles reconstituted with cytochrome $c$ oxidase and mitochondrial hydrophobic protein. J. Membrane Biol. 26:319

52. Mongar, J.L., Schild, H.O. 1958. The effect of calcium and $\mathrm{pH}$ on the anaphylactic reaction. J. Physiol. (London) 140:272

53. Normann, T.Ch. 1970. The mechanism of hormone release from neurosecretory axon endings in the calliphora erythrocephala. In: Aspects of Neuroendocrinology. W. Bargmann and B. Scharrer, editors. p. 30. Springer Verlag, Berlin-Heidelberg-New York

54. Papahadjopoulos, D., Jacobson, K., Poste, G., Sheppard, G. 1975. Effects of local anesthetics on membrane properties. I. Changes in the fluidity of phospholipid bilayers. Biochim. Biophys. Acta 394:504

55. Papahadjopoulos, D., Poste, G., Schaeffer, B.E., Vail, W.J. 1974. Membrane fusion and molecular segregation in phospholipid vesicles. Biochim. Biophys. Acta 352:10

56. Papahadjopoulos, D., Vail, W.J., Hui, S., Poste, G. 1976. Studies on membrane fusion. I. Interactions of pure phospholipid membranes and the effect of fatty acids (myristic acid), lysolecithin, proteins and dimethylsulfoxide. Biochim. Biophys. Acta 448:245

57. Papahadjopoulos, D., Vail, W.J., Newton, C., Nir, S., Jacobson, K., Poste, G., Lazo, R. 1977. Studies on membrane fusion: III. Role of $\mathrm{Ca}^{2+}$-induced phase changes. Biochim. Biophys. Acta 465:579

58. Papahadjopoulos, D., Vail, W.J., Pangborn, W.A., Poste, G. 1976. Studies on membrane fusion: II. Induction of fusion in pure phospholipid membranes by $\mathrm{Ca}^{2+}$ and other divalent metals. Biochim. Biophys. Acta 448:265

59. Pesanti, E.L., Axline, S.G. 1975. Colchicine effects in lysosomal enzyme induction and intracellular degradation in the cultivated macrophage. J. Exp. Med. 141:1030

60. Poole, A.R., Howell, I.J., Lucy, L.A. 1970. Lysolecithin and cell fusion. Nature (London) $227: 810$

61. Poste, G., Reeve, P. 1972. Inhibition of virus-induced cell fusion by local anesthetics and phenothiazine tranquilizers. J. Gen. Virol. 16:21

62. Raiteri, M., Levi, G. 1973. Depletion of synaptosomal neurotransmitter pool by sudden cooling. Nature New Biol. 243:180

63. Redman, M., Banerjee, D., Howell, K., Palade, G.E. 1975. Colchicine inhibition of plasma protein release from rat hepatocytes. J. Cell Biol. 66: 42

64. Reporter, M., Raveed, D. 1973. Plasma membranes: Isolation from naturally fused and lysolecithin-treated muscle cells. Science 181:863

65. Röhlich, P., Anderson, P., Uvnäs, B. 1971. Electron microscope observations on compound 48/80-induced degranulation in rat mast cells. J. Cell Biol. 51:465

66. Rose, B., Loewenstein, W.R. 1976. Permeability of a cell junction and the local cytoplasmic free ionized calcium concentration: A study with aequorin. J. Membrane Biol. 28:87

67. Rubin, R.P., Miele, E. 1968. The relation between the chemical structure of local anesthetics and inhibition of calcium-evoked secretion from the adrenal medulla. Naunyn-Schmiedeberg Arch. Pharmacol. Exp. Pathol. 260:298

68. Schachter, H., Jabbal, I., Hudgin, R.L., Pinteric, L., McGuire, E.J., Roseman, S. 1970. Intracellular localization of liver sugar nucleotide glycoprotein glycotransferase in a Golgi-rich fraction. J. Biol. Chem. 245:1090

69. Schudt, C., Dahl, G., Gratzl, M. 1976. Calcium-induced fusion of plasma membranes from myoblasts grown in culture. Cytobiologie $13: 211$ 
70. Schudt, C., Pette, D. 1976. Influence of monosaccharides, medium factors and enzymatic modification on fusion of myoblasts in vitro. Cytobiologie 13:74

71. Seeman, P. 1972. The membrane actions of anesthetics and tranquilizers. Pharmacol. Rev. 24:583

72. Stadler, J., Franke, W.W. 1974. Characterization of the colchicine binding of membrane fractions from rat and mouse liver. J. Cell Biol. 60:297

73. Stein, O., Sanger, L., Stein, Y. 1974. Colchicine induced inhibition of lipoprotein and protein secretion into the serum and lack of interference with secretion of biliary phospholipids and cholesterol by rat liver in vivo. J. Cell Biol. 62:90

74. Thorn, N.A., Russell, J.T., Dahl, G., Gratzl, M. 1976. Studies on the mechanism of antidiuretic hormone release. In: Proceedings of International Conference on the Neurohypophysis. A. Moses and M. Miller, editors. Karger, Basel (in press)

75. Winquist, L., Erikson, L., Dallner, G., Ersson, B. 1976. Binding of glycoproteins of microsomal and Golgi membranes to lectins. Biochim. Biophys. Res. Commun. 58:1020 